\title{
Pemberdayaan Ekonomi Berbasis Kearifan Lokal Sebelum dan Sesudah Pengalokasian Dana Desa
}

\author{
Udik Jatmiko \\ Prodi Manajemen Fakultas Ekonomi \\ Universitas Islam Kadiri Kediri \\ udikjatmiko@uniska-kediri.ac.id
}

\begin{abstract}
The Implementation of this research was intended to knows the difference based community economic empowerment local knowledge before and after the village to the allocation of funds. This study applies quantitative approach with comparative study using 67 business operators as population, sample determined as many as 32 business operators while purposive technique the sampling metodh of. The research was conducted at Paron Village Government Subdistrict Kediri Regency. Data analysis technique that is used paired sample t test. The research indicated that the outcome of the findings in an empirical manner the result of study to show the local wisdom based economic empowerment village before the allocation of funds differ significantly by empowering the local wisdom economy after the village funds. The existence of village funds has changed the economic condition with the utilization of local raw materials as the basis for developing small business based local wisdom. Village funds are also used to create tourism villages that are expected to support the economy of citizens.
\end{abstract}

Keywoards: Economic Empowerment, Local Wisdom, Village Funds.

\begin{abstract}
Abstrak
Pelaksanaan penelitian ini dimaksudkan untuk mengetahui perbedaan pemberdayaan ekonomi masyarakat berbasis kearifan lokal sebelum dan sesudah adanya pengalokasian Dana Desa. Penelitian ini menggunakan pendekatan kuantitatif komparatif dengan populasi sebanyak 67 pelaku usaha, sedangkan sampel ditentukan sebanyak 32 pelaku usaha dengan teknik purposive sampling. Objek penelitian ini dilakukan di Pemerintah Desa Paron Kecamatan Ngasem Kabupaten Kediri. Teknik yang digunakan dalam proses menganalisa dengan uji paired sample t test. Hasil temuan penelitian ini menunjukkan bahwa Secara empiris hasil penelitian yang menyatakan pemberdayaan ekonomi berbasis kearifan lokal sebelum pengalokasian Dana Desa berbeda secara signifikan dengan pemberdayaan ekonomi berbasis kearifan lokal sesudah adanya Dana Desa. Keberadaan Dana Desa telah merubah kondisi ekonomi masayarakat dengan pemanfaatan bahan baku lokal sebagai dasar mengembangkan usaha kecil berbasis kearifan lokal. Dana Desa juga digunakan untuk menciptakan Desa wisata yang diharapkan dapat menunjang perekonomian warga.
\end{abstract}

Kata Kunci: Pemberdayaan Ekonomi, Kearifan Lokal, Dana Desa

Alamat korespondensi :

Universitas Islam Kadiri, Kediri Jawa Timur

Jl. Sersan Suharmadji No. 38 Kota Kediri 


\begin{tabular}{lcl}
\hline Permalink/DOI & $:$ & http://dx.doi.org/10.32503/jmk.v5i2.1007 \\
Cara Mengutip & $:$ & Jatmiko, Udik. (2020). Pemberdayaan Ekonomi Berbasis \\
& & Kearifan Lokal Sebelum dan Sesudah Pengalokasian Dana Desa. \\
& JMK (Jurnal Manajemen dan Kewirausahaan), 5 (2), 107-121 \\
& doi: http://dx.doi.org/10.32503/jmk.v5i2.1007 \\
Sejarah Artikel $\quad:$ & $\begin{array}{l}\text { Artikel diterima 5 April 2020; direvisi 15 April 2020; disetujui } \\
\end{array}$ \\
& 29 April 2020
\end{tabular}

\section{Pendahuluan}

Realitas keadaan saat ini di wilayah pedesaan adalah pelaksanaan pembangunan yang menjadi hal utama bagi Pemerintah Desa, Pemerintah Kabupaten/Kota hingga menjadi tujuan utama Pemerintah Pusat sebagai upaya dalam meningkatkan kesejahteraan masyarakat di kalangan pedesaan. Dalam mensukseskan tujuan tersebut diperlukan sejumlah dukungan materiil berupa pemberian pendanaan dari pihak Pemerintah Pusat maupun Pemerintah Daerah yang kemudian disalurkan kepada Pemerintah Desa untuk dialokasikan menjadi sumbersumber pemberdayaan masayarakat baik sebagai bentuk pengembangan infrastruktur atau sebagai jalan meningkatkan pemberdayaan ekonomi masyarakat pedesaan, salah satunya dengan pengalokasian dan keberadaan Dana Desa yang diterima dari Pemerintah dalam hal ini Kementrian Keuangan dan Kementrian Pedesaan kepada Pemerintah Desa (Sofianto, 2017).

Sumber keuangan Desa yang berasal dari Dana Desa diberikan Pemerinah pada awal tahun 2015. Berdasarkan peraturan perundangan keberadaan Desa dianggap sebagai pioner atau akar dari perkembangan pembangunan dan peningkatan status ekonomi masyarakat. Pemerintah Desa mempunyai hak dan kewenangan untuk memperolah sumber pendanaan yang dapat digunakan untuk melakukan pengelolaan potensi yang dimiliki setiap Desa. Setiap periode tahunan pihak pemerintah melakukan pencairan penganggaran yang dikhususkan untuk Desa-Desa, pada awal tahun 2015 data Dana Desa yang tersalurkan sebesar 20,7 trilliun rupiah dengan rincian perolehan ratarata setiap Desa sebesar 280 juta rupiah per periode penganggarannya (Kementerian Keuangan Republik Indonesia, 2017)

Pengalokasian Anggaran Dana Desa yang diberikan selama ini masih dirasa kurang maksimal dan memerlukan penyempurnaan, baik tugas masyarakat dan Pemerintah Desa khususnya mampu melakukan perencanaan, pengelolaan dan melakukan supervisi atas laporan penggunaan Dana Desa. Realita yang saat ini terjadi Pemerintah Pusat terus berharap bahwa anggaran Dana Desa semakin berpihak kepada masayarakat miskin dengan menyusun regulasi mengenai prosedur pengelolaan Dana Desa yang transparan dan memiliki unsur akuntabiitas, sehingga untuk mencapai regulasi tersebut diperlukan penguatan dari aspek sumber daya manusia dan secara kelembagaan mulai dari masyarakat, Pemerintah Desa hingga Pemerintah Daerah. Hal ini, dimaksudkan agar tugas pokok dan fungsi Desa dalam menyelenggarakan administrasi pemerintahan dan progres pembagunan daerah dalam segala 
aspek dilaksanakan sesuai kewenangannya sesuai peraturan Undang-undang Nomor 6 Tahun 2014 tentang Desa yang menyatakan bahwa Pemerintah Desa diberikan mandat untuk mengelola dan mengalokasikan Dana Desa. Pada Tahun 2019 di Wilayah Kabupaten Kediri terdapat 343 Desa, alokasi dana desa per desa diberikan sebesar Rp.672.421.000,setiap periode tahunan (Kementerian Keuangan Republik Indonesia, 2019)

Pengalokasian Dana Desa juga ditekankan oleh Pemerintah Desa Paron Kecamatan Ngasem Kabupaten Kediri, di Tahun 2015 pada awal penetapan dan penganggaran Dana Desa alokasi anggaran tersebut dilakukan untuk kegiatan pengembangan infrastruktur desa melalui pembangunan-pembangunan akses jalan, irigasi persawahan dan tempat ibadah serta fasilitas umum masyarakat Desa Paron (Pemerintah Desa Paron, 2015). Berbeda dengan pelaksanaan anggaran Tahun 2017 pergeseran alokasi dana desa diarahkan ke wilayah pemberdayaan ekonomi masyarakat berbasis kearifan lokal. Seperti penciptaan wirausahawan baru di wilayah pedesaan dengan tidak meninggalkan potensi hasil-hasil pertanian di Desa Paron, menciptakan Desa Wisata dengan pengoptimalan lokasi-lokasi yang mampu menarik perhatian para pengunjung untuk meningkatkan kapasitas dan ketahanan ekonomi para pelaku usaha di Desa tersebut. Pelaksanaan alokasi anggaran Dana Desa dilakukan dengan melbatkan masyarakat setempat melalui strategi swakelola, pemaksimalan tenaga kerja yang berasal dari Desa dan memanfaatkan potensi serta bahan baku yang berasal dari tingkat lokas Desa Paron. Maksud adanya swakelola usaha adalah pengelolaan usaha mandiri yang di terapkan kepada masayarakat secara individu atau golongan oleh Pemerintah Desa Paron, sehingga keuntungan dan benefit yang digunakan untuk penguatan ekonomi di wilayah pemberdayaan masyarakat tidak mengalir keluar Desa dengan pengoptimalisasian kelembagaan melalui BUMDES. Dengan mengunakan tenaga lokal dan penciptaan wirausahawan baru diharapkan dapat menyerap para penganguran yang ada di Desa dan mampu memberikan pendapatan bagi masyarakat Desa setempat (Pemerintah Desa Paron, 2017).

Kondisi pemberdayaan ekonomi masyarakat Desa Paron saat ini masih belum bisak dikatakan maksimal, hal ini terlihat dari tingkat pengetahuan warga terkait alokasi Dana Desa yang dapat dipergunakan sebagai faktor pemberdayaan ekonomi masih rendah, tingkat kemampuan dan kemauan warga Desa Paron yang tergolong masih minim dari penciptaan dan inisiatif membangun usaha mandiri. Masalah lainnya juga muncul dari kebijakan Pemerintah Desa Paron yang membuat program alokasi Dana Desa yang belum memberikan pembelajaran bagi warganya. Hasil kajian terdahulu menjelaskan bahwa pemberdayaan masyarakat desa dapat diperoleh dari gagasan dan kemampuan warga dalam mengekspresikan dan memyumbangkan gagasan dalam meningkatkan kualitas kesejahteraan secara bebas dan tanpa tekanan (Putra et al., 2013). Pemberdayaan ekonomi masyarakat dapat di mulai dengan memberikan motivasi dan penguatan pemikiran warga Desa melalui program kegiatan non fisik. Kegiatan tersebut meliputi adanya pelaksanaan pembekalan keterampilan menjahit, 
kerajinan tangan dan mengelola organisasi kepemudaan Desa dengan melakukan penyuluhan untuk meningkatkan kemampuan menghasilkan sebuah lapangan usaha yang baru ditingkat pedesaan (Ruru et al., 2017).

Desa Paron Kecamatan Ngasem merupakan bagian wilayah pemerintahan desa yang wilayah geografisnya memiliki kepadatan pendudukan dengan jumlah 23 RT dan $8 \mathrm{RW}$ yang terbagi dengan luas wilayah pedesaan dan persawahan. Dalam menjalankan roda pemerintahan Desa yang berkaitan dengan pemberdayaan ekonomi desa, terdapat problematika bahwa pada tahun 2015 hingga akhir 2019 ditemukan bahwa BUMDES (Badan Umum Milik Desa) belum bekerja secara maksimal dalam menerapkan otonomi Desa. Masih terdapat masalah kurangnya pemahaman dan pengetahuan mengenai prosedur tata kelola anggaran Dana Desa dalam melakukan pengadaan serta minimnya sumber daya Pemerintah Desa yang kurang berkualitas yang ditugaskan mengelola alokasi dana desa tersebut. Masalah lain yang terjadi saat ini juga terlihat dari tidak efektifnya advokasi dan supervisi yang di lakukan atas perkembangan pengelolaan Dana Desa tersebut. Pihak Desa belum menunjukkan efektivitas keberadaan BUMDESnya melalui pemberdayaan ekonomi kemasyarakatan. Badan Usaha Milik Desa yang kemudian disebut BUMDes merupakan kelembagaan yang terdapat dalam satuan Pemerintah Desa, dibentuk sebagai Badan otonom untuk kebijakan pemberian dan penjamin modal usaha atas inisiatif masyarakat Desa setempat, yang berasaskan kemandirian kelembagaan. BUMDes dalam melaksanakan kegiatannya memiliki tugas menghimpun dana atau modal dari masyarakat, serta mempunyai kewenangan untuk mendapatkan sumber pendanaan dari Pemerintah baik tingkatan Desa, Daerah ataupun Pusat serta sumber pendanaan dari pihak Ketiga (Pemerintah Republik Indonesia, 2014). Belum maksimalnya BUMDES yang berjalan saat ini, dikarenakan kelembagaan permodalan yang menjamin kesejahteraan masyarakat secara mandiri, tidak efektif membuat kebijakan usaha yang berbasis kearifan lokal serta tidak optimal dalam pengembangan pemberdayaan ekonomi masayarakat Desa. Pemerintah Desa juga perlu memperhatikan minat masyarakat yang beroirientasi kepada aspek kewirausahaan, oerientasi kewirausahaan yang jelas dan detail akan membantu mencapai keberlangsungan kinerja para pelaku usaha (Jatmiko, 2016).

Masalah pemberdayaan ekonomi pedesaan juga harus melibatkan partisipasi masyarakat. Rendahnya kontribusi masyarakat yang tidak memahami penggunanaan alokasi Dana Desa, membuat partisipasi warga desa tidak secara menyeluruh dapat terserap. Penyusunan perencanaan dan pelaksanaan kegiatan juga dibuat oleh pihak-pihak yang dianggap mempunyai kepentingan, sehingga tidak mampu menyerap kebutuhan akan peningkatan mutu ekonomi warganya. Sehingga, alokasi pendanaan tersebut hanya terbatas pada pemenuhan belanja desa atas dasar kegiatan pembangunan desa, meskipun memiliki dampak positif dengan adanya penambahan fasilitas dan aset Desa. Namun, kurangnya partisipasi masyarakat Desa tersebut 
menyebabkan tujuan adanya Dana Desa untuk keperluan pemberdayaan ekonomi tidak tersalurkan secara optimal. Hal ini membuat prosentase alokasi Dana Desa hanya berimplikasi pada meningkatnya investasi pembangunan infrastruktur, namun lemah dalam hal penguatan ekonomi dan sosial di masyarakat (Harning \& Amri, 2016). Beberapa tahapan dalam melakukan pengelolaan Dana Desa melalui tahap perencanaan, pelaksanaan, pengawasan serta pertanggungjawaban pelaporan. Masih kurang maksimalnya Pemerintah Desa melaksanakan tahapan tersebut, faktor yang mempengaruhinya adalah kebijakan yang diambil Pemerintah Desa dan kualitas tenaga pengelola. Hambatan pengelolaan Dana Desa dikarenakan rendahnya sinkronisasi antara rencana Desa dengan pihak Kecamatan. Alokasi Dana Desa juga terbatas untuk aspek operasional administrasi, serta kurang intensif dalam melakukan sosialisasi pada masyarakat (Sari, 2015).

Penelitian ini dilakukan dengan melihat permasalahan belum efektifnya Pemerintah Desa Paron dalam mengambil kebijakan dalam meningkatkan kapasitas pemberdayaan ekonomi warga desa melalui penciptaan dan penguatan kemandirian masyarakat desa dalam mengelola hasil bumi atau bahan baku lokal yang mempunyai nilai ekonomis guna kesejahteraan warga desa Paron. Berdasarkan problematika yang di sampaiakan maka peneliti mengkaji efektifitas dalam pengalokasian dana desa sebagai wujud pemberdayaan ekonomi kemasayarakatan Desa yang mampu berdiri sebagai desentralisasi otonomi Desa yang kuat khususya di wilayah Pemerintah Desa Paron Kecamatan Ngasem Kabupaten
Kediri.

\section{Tinjauan Pustaka}

\section{Dana Desa}

Dana Desa merupakan anggaran pendanaam yang di kelola berdasarkan Anggaran Pendapatan dan Belanja Negara (APBN), di pergunakan bagi Pemerinah Desa melalui rekening Pemerintah Kabupaten/Kota bersumberkan Anggaran Pendapatan dan Belanja Daerah (APBD) guna menunjang pelaksanaan dan penyelenggaraan Pemerintahan Desa dengan melakukan kegiatan pembangunan Desa, dan pembnaan kesamayarakatan. Dana Desa menjadi bagian pendanaan yang krusial dalam Undang-undang Desa, anggaran tersebut diperhitungkan dari jumlah Desa dengan pertimbangan angka kepadatan penduduk, tingkat kemiskinan, luas wilayah dan kesulitan akses geografis dalam rangka peningkatan mutu dan kesejahteraan serta pemerataan perkembangan pembangunan Desa. Berdasarkan urgensi tersebut, maka Pemerintah Pusat menilai perlu adanya suatu pembinaan khusus dalam pengawasan penyelenggaraan kegiatan Desa secara menyeluruh (Kementerian Keuangan Republik Indonesia, 2014).

Kebijakan mengenai anggaran Dana Desa diperoleh dari Hasil Pajak Terbagi dan Dana Perimbangan Keuangan Pemerintah Pusat serta keuangan Daerah yang nantinya diterima setiap Kabupaten/Kota. Pendanaan yang berasal dari pemerintah Daerah tersebut nantinya menjadikan sebagai sumber pendanaan Desa secara keseluruhan sekaligus memberi kewenangan yang 
menjadi tanggung jawab setiap Desa dalam pengelolaannya. Keberadaan Dana Desa tersebut di prioritaskan untuk kegiatan penyelenggaraan pemerintahan, pembangunan fisik, pemberdayaan masyarakat dan kegiatan sosial kemasyarakatan.

Peraturan Perundang-undangan Nomor 6 Tahun 2014 tentang Desa menyebutkan bahwa Pemerintah Desa diberikan kewenangan untuk mengatur dan mengurus kebutuhan dan prioritas kegiatan Desa sesuai dengan kewenangan yang telah ditetapkan. Peraturan tersebut menandai bahwa Pemerintah Desa secara penuh memiliki kewenangan dalam menyusun rencana keguatan Desa sesuai alokasi Dana Desa yang tersusun sebagai upaya dalam pengoptimalan kinerja Desa dalam mendukung program pembangunan desa dan pemberdayaan masyarakat, maka dari itu Pemerintah Desa dituntut bertangungjawab secara penuh dalam hal pengelolaan Dana Desa.

Penggunaaan Dana Desa diprioritaskan mengenai kegiatan yang meliputi : a). Pembangunan, pengembangan dan memelihara infrastruktur atau sarana. b). Pemeliharaan dan perkembangan sarana prasarana pada aspek pendidikan, sosial, dan kebudayaan. c). Pelaksanaan perkembangan usaha perekonomian masyarakat melalui sarana produksi dan distribusi dan/atau. d). Pembangunan dan pemeliharaan sarana prasarana penguatan energi yang terbarukan serta pelestarian lingkungan hidup. Perihal pemberdayaan kemasyarakatan Desa, alokasi Dana Desa dapat diperuntukkan sebagai pengembangan wirausaha, untuk peningkatakan kapasitas pendapatan, serta perluasan wilayah atau skala usaha ekonomi masyaarakat baik individu ataupun kelompok masyarakat Desa (Kementerian Desa Pembangunan Daerah Tertingal dan Transmigrasi, 2015).

\section{Pemberdayaan Ekonomi}

Pemberdayaan merupakan suatu kegiatan yanng mengupayakan pengembangan sikap, pengetahuan, keterampilan, perilaku, kemampuan, kesadaran serta sumber daya yang dimanfaatkan sebagai bentuk suatu kebijakan dan program serta kegatan pendampingan masyarakat yang sesuai esensi permasalahan dan kepentingan kebutuhan masyarakat desa, hal ini tertuang dalam Peraturan Perundang-undangan Nomor 6 Tahun 2014 tentang Desa.

Pemberdayaan masyarakat merupakan kemampuan individu atau golongan di tengah masyarakat Desa yang mempunyai senyawa dengan interaksi kepada warga Desa lainnya untuk membangun koneksi dan legitimasi penguatan wilayah Desa. Dengan memperkuat unsur-unsur elemen kemasyarakatan yang dapat memperbaiki harkat dan martabat serta keadaan warga Desa dari ketidakberadaan dalam aspek kesenjangan ekonomi dengan menumbuhkan minat dan mengandalkan potensi, sehingga kemiskinan dan keterbelakangan dapat teratasi dan layak disebut memperdayakan masayarakat dalam konteks kemandirian Desa (Anwar, 2012).

Menurut (Rothman et al., 1995) menjelaskan bahwa dalam teori yang diungkapkan mengenai pemberdayaan masyarakat, dapat ditunjang dengan metode : pengembangan lokal, perencanaan sosial dan aksi sosial. Metode 
penggunaan pengembangan lokal dimaksudkan dapat terjadi bila terdapat peran serta masayarakat, yang aktif di semua lapisan masyarakat. Partisipasi masyarakat tersebut terlihat dari penentuan tujuan maupun pelaksanaan tindakan perubahan yang tersusun dan terencana. Masyarakat dirangsang untuk dapat menumbuhkan kondisi sosial ekonomi yang memiliki perembangan bagi taraf kehidupannya berdasarkan atas kepercayaan yang dibebankan kepada setiap masyarakat atas ide atau gagasannya. Selanjutnya, metode lain yang dapat digunakan dalam pemberdayan mengenai strategi perencanaan sosial (Social Planning Metodh) yang menekankan kepada patologi (masalah sosial) yang secara teknis dapat mempengaruhi aktivitas sosial masyarakat meliputi meminimalisir kenakalan remaja, keberadaan permukiman (perumahan), memperkuat mental masyarakat secara energi maupun fisik. Model seperti ini dianggap penting dengan melakukan perubahan-perubahan paradigma masyarakat secara rasional dan terus dilakukan kebijakan pengawasan secara rutin terkait perkembangan perubahan-perubahan sosial di masyarakat tersebut. Metode pengembangan pemberdayaan masyarakat juga bisa dilakukan dengan aksi sosial (Social Action) yang menekankan kepada aksi pemangku kebijakan yang mampu menciptakan pemerataan baik secara perluasan wilayah atau peningkatan ekonomi warga. Tujuan metode ini dengan mendasari pada perubahan lembaga-lembaga utama di masyarakat, dengan melibatkan tenaga-tenaga lokal untuk menciptakan keselarasan kegiatan dalam pengelolaan sumber-sumber serta pembuatan keputusan yang mendasari kebijakan yang akan dijalankan sebagai kebiasaan di masyarakat (Hikmat, 2010).

Pemberdayaan masyarakat Desa dapat dilakukan dengan pemenuhan kebutuhan yang bersifat psikis atau materiil, dengan mengedepankan aspek akses, partisipasi, kontrol dan kebermanfaatan. Aspek akses dimaksudkan pada kegiatan dan kewajiban yang sepadan setiap individu masyarakat dalam mengelola sumber daya yang produktif di lingkungan sekitar. Kemudian aspek partisipatif juga menjadi penting dikarenakan setiap wialayah memiliki keterbatasan sumber daya, maka dari itu masyarakat ikut serta dalam mendayagunakannya dalam pemenuhan kebutuhan. Aspek kontrol ditekankan pada kesamaan hak antara masayarakat laki-laki ataupun perempuan, dimana kebebasan menyampaikan ide dan gagasan dalam mengontrol pemanfaatan sumber daya sangat diperlukan. Aspek terakhir yang dipertimbangkan adalah kebermanfaatan, artinya setiap lapisan masyarakat memiliki kesempatan yang sama dalam merasakan dan menikmati perkembangan pembangunan, output dari pemanfaatan sumber atau potensi secara bersama.

Strategi pemberdayaan memiliki maksut dan tujuan yang beraneka ragam, secara spesifikasi dapat dijelaskan bahwa dikatakan oleh (Mardikanto \& Soebianto, 2013), yaitu :

1) Peningkatan Perbaikan Pendidikan Perbaikan-perbaikan ditingkatan pendidikan dapat dilakukan melalui cara penyampaian materi, metode dari fasilitator dan penerima informasi, dan yang terpenting adalah pertumbuhan 
minat semangat belajar semasa hidup.

2) Peningkatan Akses

Perbaikan unsur aksesibilitas dalam penguatan sumber informasi, pendanaan, penyedia peralatan dan produk rumah tangga serta lembaga pemasaran yang mampu menampung output dari ide dan gagasan dari bisnis atau usaha masyarakat.

3) Perbaikan Tindakan

Atas dasar perbaikan yang telah dilakukan di wilayah pendidikan dan akses informasi, diharapkan akan terjadi aksi nyata yang lebih baik.

4) Perbaikan Kelembagaan

Diharapkan pemberdayaan mampu meningkatkan kinerja admisnitrasi secara kelembagaan dengan memperkuat jaringan-jaringan dan hubungan baik dengan pihak lain yang berkontribusi nyata.

5) Perbaikan Usaha

Usaha yang dijalankan diharapkan dapat meningkat baik dari awal pengadaan, proses hingga keluaran.

6) Peningkatan Pendapatan

Usaha yang notabene baik, maka akan mempengaruhi profitabilitas pelaku usaha secara individu, kelompok amupun pendapatan masayarakat setempat.

7) Perubahan Lingkungan

Lingkungan fisik dan non fisik diharapkan dapat menjadi perhatian utama untuk dijaga demi kelestarian.

8) Kelayakan Kehidupan

Keadaan lingkungan yang kondusif dan pemerataan pendapatan yang sama, dapat meningkatan kesejahteraan dan kelayakan kehidupan keluarga atau masyarakat.

9) Perubahan Pola bermasyarakat
Perubahan pola bermasyarakat yang relevan, kreatif dan mampu berkarya dapat terwujud apabila masyarakat juga mendapatkan kehidupan yang layak dari perubahannya.

\section{Metodologi Penelitian}

Penelitian yang dilakukan ini menggunakan jenis kuantitatif deskriptif, dengan pendekatan perbandingan (komparatif) antara satu jenis variabel atau lebih dengan satuan waktu yang berbeda (Sugiyono, 2017). Kajian komparatif yakni fakta-fakta atau sifat-sifat dari kajian objek yang sama atau berbeda, kemudian dilakukan perbandingan atau persamaan dalam konstruk pemikiran tertentu yang ilmiah (Nazir, 2013). Populasi meliputi seluruh kelompok atau atau individu yang menjadi binaan Pemerintahan Desa Paron Kecamatan Ngasem dalam kaitannya dengan Usaha ekonomi kerakyataan sebanyak 67 pelaku usaha. Sampel merupakan sebagaian dari jumlah anggota populasi yang dipilih untuk diteliti (Ferdinand, 2014). Dalam penelitian ini sampel yang digunakan sebanyak 32 pelaku usaha, diperoleh dengan metode purposive sampling (Widiyanto \& Darmawan, 2019). Pengujian instrumen kuisioner dilakukan dengan uji validitas dan reliabilitas (Siregar, 2014). Teknik menganalis data dalam proses pengolahan menggunakan uji paired sample t tes (Quadratullah, 2014).

\section{Hasil}

Pada penelitian ini akan dijabarkan keluaran (output) pengolahan data dari instrumen penelitian sebagai berikut : 
1. Uji Validitas Pemberdayaan Ekonomi Sebelum Pengalokasian Dana Desa

Tabel 1.Uji Validitas Instrumen Pertama

\begin{tabular}{cccc}
\hline Item & $\begin{array}{c}\text { Nilai r } \\
\text { hitung }\end{array}$ & $\begin{array}{c}\mathrm{r} \text { tabel } \\
(5 \%)\end{array}$ & $\begin{array}{c}\text { Kepu } \\
\text { tusan }\end{array}$ \\
\hline Item 1 & 0,673 & 0,361 & Valid \\
\hline Item 2 & 0,528 & 0,361 & Valid \\
\hline Item 3 & 0,785 & 0,361 & Valid \\
\hline Item 4 & 0,554 & 0,361 & Valid \\
\hline Item 5 & 0,431 & 0,361 & Valid \\
\hline Item 6 & 0,561 & 0,361 & Valid \\
\hline Item 7 & 0,743 & 0,361 & Valid \\
\hline Item 8 & 0,652 & 0,361 & Valid \\
\hline \multicolumn{4}{l}{ Sumber : Data Diolah, 2020 }
\end{tabular}

Berdasarkan tabel 1 di atas, maka dapat dijelaskan secara keseluruhan intrumen pemberdayaan ekonomi sebelum pengalokasian Dana Desa dapat dikatakan valid dengan nilai $r_{\text {hitung }}$ berada di atas ketentuan dengan nilai $\mathrm{Df}=\mathrm{n}-2=32-2=30$, maka $\mathrm{r}_{\text {tabel }}$ sebesar 0,361. Hasil tersebut menjelaska bahwa kuisioner yang diberikan kepada responden sebanyak 8 item dapat disimpulkan valid dan berada di atas kriteria yang ditentukan.

2. Uji Validitas Pemberdayaan Ekonomi Sesudah Pengalokasian Dana Desa

Tabel 2.Uji Validitas Intrumen Kedua

\begin{tabular}{cccc}
\hline Item & $\begin{array}{c}\text { Nilai r } \\
\text { hitung }\end{array}$ & $\begin{array}{c}\mathrm{r} \text { tabel } \\
(5 \%)\end{array}$ & $\begin{array}{c}\text { Kepu } \\
\text { tusan }\end{array}$ \\
\hline Item 1 & 0,621 & 0,361 & Valid \\
\hline Item 2 & 0,592 & 0,361 & Valid \\
\hline Item 3 & 0,557 & 0,361 & Valid \\
\hline Item 4 & 0,682 & 0,361 & Valid \\
\hline Item 5 & 0,536 & 0,361 & Valid \\
\hline Item 6 & 0,572 & 0,361 & Valid \\
\hline Item 7 & 0,486 & 0,361 & Valid \\
\hline Item 8 & 0,762 & 0,361 & Valid \\
\hline Sumber : Data Diolah, 2020 &
\end{tabular}

Berdasarkan tabel 2 di atas, maka dapat dijelaskan bahwa item secara keseluruhan intrumen pemberdayaan ekonomi sesudah pengalokasian Dana Desa dapat dikatakan valid dengan nilai $r_{\text {hitung }}$ berada di atas ketentuan dengan nilai $\mathrm{Df}=\mathrm{n}-2=32-2=30$, maka $r_{\text {tabel }}$ sebesar 0,361. Bahwa kuisioner yang diberikan kepada responden sebanyak 8 item dapat disimpulkan valid dan berada di atas kriteria yang ditentukan pada penelitian ini.

3. Hasil Uji Reliabilitas

Tabel 3.Uji Reliabilitas

\begin{tabular}{|c|c|c|c|}
\hline $\begin{array}{c}\text { Item } \\
\text { Variabel }\end{array}$ & $\begin{array}{c}\text { Nilai } \\
\text { Alpha } \\
\text { Cronboa } \\
\text { ch }\end{array}$ & $\begin{array}{c}\text { Nilai } \\
\text { Keten } \\
\text { tuan }\end{array}$ & $\begin{array}{c}\text { Keput } \\
\text { usan }\end{array}$ \\
\hline $\begin{array}{l}\text { Pemberda } \\
\text { yaan } \\
\text { ekonomi } \\
\text { Sebelum } \\
\text { Dana Desa }\end{array}$ & 0,783 & 0,60 & $\begin{array}{c}\text { Relia } \\
\text { bel }\end{array}$ \\
\hline $\begin{array}{l}\text { Pemberda } \\
\text { yaan } \\
\text { ekonomi } \\
\text { sesudah } \\
\text { Dana Desa }\end{array}$ & 0,853 & 0,60 & $\begin{array}{c}\text { Relia } \\
\text { bel }\end{array}$ \\
\hline
\end{tabular}

Berdasarkan Tabel 3 diatas, maka dapat disampaikan secara keseluruhan bahwa intrumen yang digunakan untuk mengukur pemberdayaan ekonomi sebelum dan sesudah dana desa diperoleh nila di atas 0,60. Hal ini dapat dikatakan bahwa instrumen tersebut dikatakan reliabel dan dapat dipercaya

4. Hasil Uji Beda Rata-Rata Pemberdayaan Ekonomi Sebelum dan Sesudah Pengalokasian Dana Desa: 
Tabel 4.Uji Beda Rata-rata

\begin{tabular}{lcccc}
\hline Item Variabel & Mean & $\mathrm{N}$ & $\begin{array}{c}\text { Std. } \\
\text { Devia } \\
\text { tion }\end{array}$ & $\begin{array}{c}\text { Std. } \\
\text { Error } \\
\text { Mean }\end{array}$ \\
\hline $\begin{array}{l}\text { Pemberdayaan } \\
\text { ekonomi }\end{array}$ & 34,08 & 32 & 2,873 & 0,305 \\
$\begin{array}{l}\text { Sebelum Dana } \\
\text { Desa }\end{array}$ & & & & \\
\hline $\begin{array}{l}\text { Pemberdayaan } \\
\text { ekonomi } \\
\text { sesudah Dana } \\
\text { Desa }\end{array}$ & 30,31 & 32 & 3,253 & 0,345 \\
\hline \multicolumn{1}{c}{ Sumber: Data Diolah, 2020 } & & \\
\hline
\end{tabular}

Hasil perhitungan tabel 4 di atas, menunjukkan bahwa dari 32 responden yaitu kelompok atau individu yang melakukan usaha diperoleh nilai rata-rata (mean) Pemberdayaan ekonomi sebelum dilakukannya pengalokasian Dana Desa sebesar 34,08 dengan standar deviasi 2,873. Sedangkan rata-rata pemberdayaan ekonomi Dana Desa dilakukannya pengalokasian Dana Desa sebesar 30,31 dengan standart deviasi sebesar 3,253. Hasil perhitungan tersebut menunjukkan bahwa perbedaan pengalokasian dana desa yang diberikan Pemerintah Desa Paron mengalami peningkatan untuk aspek pemberdayaan ekonomi.

5. Hasil Uji Korelasi Pemberdayaan Ekonomi Sebelum dan Sesudah Pengalokasian Dana Desa

\section{Tabel 5.Uji Korelasi}

\begin{tabular}{lccc}
\multicolumn{1}{c}{ Variabel } & $\mathrm{N}$ & $\begin{array}{c}\text { Corr } \\
\text { elatio } \\
\mathrm{n}\end{array}$ & Sig. \\
\hline $\begin{array}{l}\text { Pemberdaya } \\
\text { an Ekonomi }\end{array}$ & & & \\
$\begin{array}{l}\text { Sebelum \& } \\
\text { Sesudah }\end{array}$ & 32 & .643 & .003 \\
Dana Desa & & & \\
\hline Sumber : Data Diolah, 2020 & &
\end{tabular}

Hasil perhitungan di atas dapat dijelaskan bahwa hubungan antara variabel pemberdayaan ekonomi sebelum dan sesudah adanya pengalokasian dana desa berhubungan secara nyata dalam kategori kuat, hal ini juga dibuktikan dengan nilai Signifikasinya $<0,05$.

6. Hasil Uji Hipotesis Pemberdayaan Ekonomi Sebelum dan Sesudah Pengalokasian Dana Desa

\section{Tabel 6.Uji Hipotesis}

\begin{tabular}{|c|c|c|c|c|c|}
\hline Variabel & Mean & $\begin{array}{c}\text { Std. } \\
\text { Deviati } \\
\text { on }\end{array}$ & $\mathrm{t}$ & $\mathrm{df}$ & $\begin{array}{l}\text { Sig. (2- } \\
\text { tailed) }\end{array}$ \\
\hline $\begin{array}{l}\text { Pemberd } \\
\text { ayaan } \\
\text { Ekonomi } \\
\text { Sebelum }\end{array}$ & & & & & \\
\hline $\begin{array}{l}- \\
\text { Sesudah } \\
\text { Pengalok } \\
\text { asian } \\
\text { Dana } \\
\text { Desa }\end{array}$ & 3,764 & 3,823 & 9,289 & 31 & 0,000 \\
\hline
\end{tabular}

Berdasarkan tabel 6 di atas, maka untuk menilai hipotesis dalam penelitian ini menggunakan pedoman bahwa :

1. Terlihat bahwa nilai $\mathrm{t}$ hitung sebesar 9,289 dengan nilai probabilitas 0,000 lebih kecil dari ketentuan 0,05. maka dapat disimpulkan bahwa Ho ditolak dan Ha diterima yang berarti terdapat perbedaan yang signifikan antara pemberdayaan ekonomi sebelum pengalokasian Dana Desa dan sesudah pengalokasian Dana Desa.

2. Hasil perhitungan tersebut juga menyatakan bahwa terjadi perbedaan nilai rata-rata (mean) sebesar 3,764 hal ini berarti terdapat selisih rata-rata pemberdayaan ekonomi sebelum pengalokasian Dana Desa dan sesudah pengalokasian Dana Desa. 


\section{Pembahasan}

Hasil pengolahan dan analisis data yang telah dilakukan dalam penelitian ini menjelaskan secara empiris bahwa terdapat perbedaan yang signifikan antara pemberdayaan ekonomi berbasis kearifan lokal sebelum pengalokasian Dana Desa dan sesudah pengalokasian Dana Desa. Hasil penelitian tersebut menjawab hipotesis yang diajukan bahwa nilai t hitung sebesar 9,289 lebih besar dibanding nilai $t_{\text {tabel }}$ sebesar 1,310 dan taraf signifikasi 0,000 berada dibawah ketentuan sebesar 0,05, artinya Ho ditolak dan Ha diterima. Secara empiris hasil penelitian yang menyatakan pemberdayaan ekonomi berbasis kearifan lokal sebelum pengalokasian Dana Desa berbeda secara signifikan dengan pemberdayaan ekonomi berbasis kearifan lokal sesudah adanya Dana Desa dapat diterima dan dinyatakan sesuai dengan hipotesis yang diajukan.

Hasil temuan penelitian ini menyatakan bahwa sebelum adanya pengalokasian Dana Desa di Wilayah Pemerintahan Desa Paron Kecamatan Ngasem, keberadaan para kelompok usaha atau usaha individu yang di bina oleh BUMDES belum maksimal dan belum menampakkan hasil yang meningkat. Ketidakmaksimalan pengelolaan usaha kerakyatan tersebut, dikarenakan adanya faktor fokus perencanaan yang di susun oleh Pemerintah Desa Paron pada Tahun 2015 adalah mengenai pembangunan infrastruktur Desa dan lebih diarahkan pada aspek pembangunan fasilitas-fasilitas, sarana fisik masyarakat yang tampak kurang memadai. Kebijakan yang diambil Pemerintah Desa Paron tersebut tidak lain adalah untuk membuat kepercayaan masyarakat tumbuh apabila fasilitas-fasiltas Desa dapat dinikmati oleh psikologi warganya, sehingga muncul partisipasi masyarakat yang antusias untuk mencari akses informasi mengenai keberadaan Dana Desa. Data pada awal pengalokasian Dana Desa untuk Pemberdayaan Ekonomi dimulai pada Tahun 2015 tingkat partipasi masyarakat dalam membentuk usahausaha yang bergerak di sektor ekonomi dengan mengedapankan bahan baku dari hasil-hasil potensi kekayaan Desa belum maksimal, terhitung pada tahun 2015 Kelompok Usaha baik dari kalangan pemuda dan ibu-ibu rumah tangga yang berkeinginan untuk partisipatif dalam membangun Desa melalui ide dan gagasan usahanya masing-masing. Anggaran Dana Desa yang sedianya di alokasikan untuk pemberdayaan ekonomi berbasis kearifan lokal tampak mengalami beberapa kendala, baik dari kemauan masyarakat untuk memulai bisnis atau mengikuti program penyuluhan yang dilaksanakan Desa. Selain itu, masalah administrasi juga menjadi pertimbangan tidak efektifnya pengelolaan Dana Desa tersebut, terbukti bahwa perencanaan yang disusun pihak Desa melalui Musyawarah Rembug dan pengembangan Desa belum sesuai dengan tuuan dan harapan Pemerintah Desa. Hal ini membuat kegiatan ekonomi kemasyarakatan di Desa Paron menjadi terhambat karena tidak sejalan dengan prosentase Alokasi Anggaran Dana desa (ADD) yang telah disalurkan oleh Pemerintah Desa kepada individu atau kelompok usaha tersebut.

Perbedaan yang signifikan terjadi pada tahun 2016 hingga akhir tahun 2019, hal ini ditunjukkan dengan 
meningkatnya jumlah partisipasi para kelompok usaha atau usaha individu yang masuk dalam pendampingan BUMDES Pemerintah Desa Paron Kecamatan Ngasem. Peningkatan jumlah pelaku usaha berbasis kearifan lokas di Desa menandai bahwa efektivitas alokasi Dana Desa untuk kepentingan pemberdayaan ekonomi masyarakat desa paron mulai mengalami pergeseran paradigma, bahwa pengembangan usaha mampu mengangkat ekonomi warga desa yang signifikan. Banyak kegiatan usaha ekonomi kerakyatan berbasis kearifan lokas seperti usaha kripik sukun, usaha keterampilan las, warung kuliner hingga usaha produk olahan hasil ternak perikanan serta menjadikan wisata Desa Paron untuk penguatan ekonomi dengan penciptaan wahana Sumber Kembangan, slaah satu ikon terbaru desa untuk tempat rekreasi dan acaraacara resmi yang diindikasikan dapat meningkatkan ekonomi desa secara signifikan. Hasil penelitian terdahulu menjelaskan bahwa perubahan pendapatan para kelompok atau usaha individu mengalami kenaikan yang signifikan dan mampu digunakan sebagai penopang kelayakan kehidupak keluarga. Peningkatan nilai taraf hidup para pelaku usaha ini juga merupakan hasil kerja keras masyarakat desa dalam menanamkan sikap berwirausaha dengan memaksimalkan potensi Desa yang ada. Daya beli masayrakatpun menjadi stabil dan dapat meningkat sedikit demi sedikit dengan menyesuaikan kebutuhan, kondisi dan lingkungan tempat tinggalnya. Anggota kelompok atau usaha individu yang didampingi BUMDES mampu menigkatkan taraf hidup dan kesenjangan kemiskinan desa dari pengalokasian Dana Desa dan strategi usaha yang tepat guna (Sofinisa et al., 2015).

Upaya Pemerintah Desa Paron dalam mengambil kebijakan untuk mengoptimalkan Pengalokasian Dana Desa melalui pemberdayaan ekonomi pedesaan berbasis kearifan lokal pada saat ini dirasa sudah baik dan dapat berjalan sesuai dengan operasional serta tujuan adanya Dana Desa. Keberadaan Dana Desa di tengahtengah masyarakat di wilayah pedesaaan mempunyai sisi positif dalam proses peningkatan pembangunan yang berkelanjutan, baik secara fisik atau dalam aspek pemberdayaan masyarakat Desa. Bukti perkembangan pembangunan Desa tersebut terwujud dari persepsi warga Desa yang mengalami kemudahan dalam beraktivitas secara lancar karena adanya perbaikanperbaikan diwilayah infrastruktur, mutu pendidikan, pola kelayakan hidup dan perubahan ekonomi setiap warga Desa. Banyaknya kegiatan desa yang menarik perhatian para pemangku kebijakan dalam hal ini penanam modal, membuat semangat masayarakat untuk berkelanjutan dalam memelihara sebuah usaha terus diperhatikan, berperan aktif dalam pertemuan ilmiah yang berhubungan dengan usaha kemandirian serta peningkatan kapasitas-kapasitas produksi dari hasil pengembangan, sehingga masyarakat mendapatkan benefit yang nyata dari pengelolaan Dana Desa yang tepat. (Sofiyanto et al., 2017). Hasil penelitian yang telah dilakukan juga menjelaskan bahwa Pemerintah Desa dan masyarakat merasa cukup terbantu dengan adanya Dana Desa yang mampu memberikan sumbangan yang cukup berarti bagi pembangunan Desa dari aspek perekonomian warga dan semakin meningkatkan efisiensi pemberdayaan 
ekonomi masyarakat Desa (Sofianto, 2017). Hasil kajian terdahulu lainnya menjelaskan bahwa pengalokasian Dana Desa secara efektif mampu mendukung program Pemerintah Desa guna meningkatkan pendapatan yang lebih baik, serta dapat meminimalisis angka kemiskinan, angka kenakalan remaja serta tentunya berkurangnya pengangguran Desa. Akan tetapi, masih diperlukan penguatan-penguatan sumber daya aparatur Pemerintahan Desa melalui teknologi tepat guna, agar kemampuan aparatur pemerintah diitngkatan Desa mampu menjawab tantangan di era kecanggihan teknologi (Tangkumahat et al., 2017)

Apabila dikaji lebih dalam mengenai adanya Dana Desa diperkuat dengan Peraturan Perundang-undangan yang dikeluarkan pemerintah Nomor 6 Tahun 2014 tentang Desa, masayarakat dapat memberikan perannya secara nyata terhadap pembangunan dalam urgensi menjaga asas demokrasi kemasayarakatan, asas musyawarah dalam mencapai mufakat, keseeraaan dan kesederajatan, gotong royong, kekeluargaan, memiliki otonomi desa, serta partisipasi penuh dalam keberlangsungan pemberdayaan potensi-potensi Desa yang mempunyai nilai guna ekonomi bagi masyarakat. Anggaran Pendapatan Belanja Negara menjadi sumber adanya Dana Desa, sebagai pengganti program PNPM Mandiri. Harapan pemerintah dengan adanya Dana Desa dapat digunakan sebagai wujud membaiknya kualitas kehidupan warga disetiap penjuru Desa-Desa, baik dari aspek kesenjangan ekonomi menjadi berkurang, hubungan dan status sosial kemasyarakatan meningkat, animo politik yang damai, dan tentunya tetap menjaga kebudayaan dan pelestarian lingkungan. Hal ini tertuang dalam Peraturan No 60 Tahun 2014 tentang Dana Desa, manakala penggunaan Dana Desa dapat diperuntukkan kepada masyarakat atas dasar musyawarah yang dirumuskan oleh Pemerintah Desa melalui APBDes, tentunya dengan persetujuan resmi Pemerintah Daerah yang ditunjuk sebagai pengawas dan kontrol dalam kebijakan pengelolaan keuangan khususnya pengalokasian Dana Desa yang menuntut kewajiban mengelola dengan transparan dan profesional (Kementrian Keuangan Republik Indonesia, 2015).

\section{Simpulan}

Setelah penjelasan analisis dan pembahasan data telah disampaiakan secara jelas, maka dalam penelitian ini dapat dijelaskan suatu kesimpulan bahwa terdapat perbedaan yang signifikan antara pemberdayaan ekonomi berbasis kearifan lokal sebelum pengalokasian Dana Desa dan sesudah pengalokasian Dana Desa. Secara empiris hasil penelitian yang menyatakan pemberdayaan ekonomi berbasis kearifan lokal sebelum pengalokasian Dana Desa berbeda secara signifikan dengan pemberdayaan ekonomi berbasis kearifan lokal sesudah adanya Dana Desa dapat diterima dan dinyatakan sesuai dengan hipotesis yang diajukan. Merujuk pada hasil penelitian tersebut, maka dapat disampaikan saran kepada pihak Pemerintah Desa Paron Kecamatan Ngasem Kabupaten Kediri dengan selalu melakukan pengawasan secara mendalam terkait peningkatan kapasitas dan keterampilan usaha individu atau kelompok yang di bina 
oleh BUMDES. Rekomendasi bagi peneliti selanjutnya agar melaksanakan analisis efektivitas sistem kinerja yang kompeten, memiliki integritas dan transparansi dalam menjalankan kegiatan penyaluran anggaran Dana Desa yang efektif dan tepat sasaran bagi masyarakat.

\section{Daftar Pustaka}

Anwar. (2012). Manajemen Pemberdayaan Perempuan. Bandung: PT. Alfabeta.

Ferdinand, A. (2014). Metode Penelitian Manajemen Pedoman Penelitian untuk Penulisan Skripsi Tesis dan disertai Ilmu Manajemen. Semarang: Universitas Diponegoro.

Harning, S. V., \& Amri, A. (2016). Dana Desa dan Kepadatan Belanja di Kecamatan Meuraxa Kota Banda Aceh. Jurnal Ilmiah Mahasiswa Ekonomi Pembangunan, 1(1), 254-261. http://jim.unsyiah.ac.id/EKP/arti cle/view/699

Hikmat, H. (2010). Strategi Pemberdayaan Masyarakat. Bandung: Humaniora Utama Press.

Jatmiko, U. (2016). Pengaruh Lingkungan Bisnis Dan Orientasi Kewirausahaan Terhadap Peningkatan Kinerja Pelaku UKM Pada Tahap StartUp Di Desa Paron Kecamatan Ngasem Kabupaten Kediri. Jurnal Manajemen \& Kewirausahaan, 1(3), 235-246. https://ejournal.uniskakediri.ac.id/index.php/Manajeme nKewirausahaan/article/view/24 7

Kementerian Desa Pembangunan Daerah Tertingal dan
Transmigrasi. (2015). Peraturan Menteri Desa, Pembangunan Daerah Tertinggal, Dan Transmigrasi No 21 Tahun 2015 tentang Penetapan Prioritas Penggunaan Dana Desa Tahun 2016.

Kementerian Keuangan Republik Indonesia. (2014). UndangUndang Nomor 6 Tahun 2014 Tentang Desa.

Kementerian Keuangan Republik Indonesia. (2017). Buku Pintar Dana Desa.

Kementerian Keuangan Republik Indonesia. (2019). Data Rincian Dana Desa Menurut Kabupaten/Kota.

Kementrian Keuangan Republik Indonesia. (2015). PMK_93PMK.07-2015.pdf.

Mardikanto, T., \& Soebianto, P. (2013). Pemberdayaan Masyarakat: Dalam Perspektif Kebijakan Publik. Bandung: PT. Alfabeta.

Nazir, M. (2013). Metode Penelitian. Bogor: Ghalia Indonesia.

Pemerintah Desa Paron. (2015). Laporan Pertanggungjawaban Penggunaan Dana Desa Periode I 2015 Desa Paron.

Pemerintah Desa Paron. (2017). Laporan Pertanggungjawaban Pengunaan Dana Desa Periode I Tahun 2017.

Pemerintah Republik Indonesia. (2014). Undang-undang No 32 Tahun 2014 Tentang Pemerintah Daerah.

Putra, C. K., Pratiwi, R. N., \& Suwondo. (2013). PENGELOLAAN ALOKASI DANA DESA DALAM PEMBERDAYAAN MASYARAKAT DESA (Studi pada Desa Wonorejo Kecamatan Singosari Kabupaten Malang). 
Jurnal Administrasi Publik Mahasiswa Universitas Brawijaya, 1(6), 1203-1212. http://administrasipublik.studentj ournal.ub.ac.id/index.php/jap/arti cle/view/193

Quadratullah, M. F. (2014). • Statistika Terapan. Yogyakarta: Penerbit Andi.

Rothman, J., Erlich, J. L., \& Tropman, J. E. (1995). Strategies of Community Intervention (Fifth Edit). Newyork: Colombia University Press.

Ruru, N., Kalangi, L., \& Budiarso, N. S. (2017). ANALISIS PENERAPAN ALOKASI DANA DESA (ADD) DALAM UPAYA MENINGKATKAN PEMBANGUNAN DESA (Studi Kasus Pada Desa Suwaan, Kecamatan Kalawat, Kabupaten Minahasa Utara). Jurnal Riset Akuntansi Going Concern, 12(1).

https://ejournal.unsrat.ac.id/inde x.php/gc/article/view/17140

Sari, R. (2015). Pengelolaan Alokasi Dana Desa Dalam Perspektif Pemberdayaan Masyarakat (Studi Pada Kantor Pemerintahan Desa Ngasem, Kecamatan Ngasem, Kabupaten Kediri). Jurnal Administrasi Publik Mahasiswa Universitas Brawijaya, 3(11), 1880-1885. http://administrasipublik.studentj ournal.ub.ac.id/index.php/jap/arti cle/view/1060

Siregar, I. S. (2014). Metode Penelitian Kuantitatif Dilengkapi Dengan Perhitungan Manual dan SPSS. Jakarta: PT. Fajar Interpratama Mandiri.

Sofianto, A. (2017). Kontribusi Dana Desa terhadap Pembangunan dan Pemberdayaan Masyarakat di Kebumen dan Pekalongan.
Matra Pembaruan, 1(1), 23-32. https://doi.org/10.21787/mp.1.1. 2017.23-32

Sofinisa, A., Haryono, B. S., \& Mindarti, L. I. (2015). Pemberdayaan Masyarakat Sebagai Upaya Meningkatkan Ekonomi Pedesaan. 3(11), 1844-1850.

http://administrasipublik.studentj ournal.ub.ac.id/index.php/jap/arti cle/view/1055

Sofiyanto, M., Mardani, R. M., \& Salim, M. G. (2017). Pengelolaan Dana Desa Dalam Upaya Meningkatkan Pembangunan Di Desa Banyuates Kecamatan Banyuates Kabupaten Sampang. Jurnal Riset Manajemen, November 2016, 124-135. http://riset.unisma.ac.id/index.ph $\mathrm{p} / \mathrm{jrm} /$ issue/view/85

Sugiyono. (2017). Metode Penelitian Kuantitatif, Kualitatif dan $R \& D$. Bandung: PT. Alfabeta.

Tangkumahat, F. V., Vicky V. J. Panelewen, \& Arie D. P. Mirah. (2017). Dampak Program Dana Desa Terhadap Peningkatan Pembangunan Dan Ekonomi Di Kecamatan Pineleng Kabupaten Minahasa. Agri-Sosio Ekonomi Universitas Sam Ratulangi Manado, 13(12A). https://ejournal.unsrat.ac.id/inde x.php/jisep/article/view/17130

Widiyanto, M. A., \& Darmawan, I. P. A. (2019). Pengaruh Kompetensi Dan Kepuasan Mengajar terhadap Prestasi Kerja Guru Agama Kristen. Kelola: Jurnal Manajemen Pendidikan. https://doi.org/10.24246/j.jk.201 9.v6.i2.p179-187 